\title{
The impact of work environment and motivation on teachers's discipline level
}

\author{
Setyani Setyani ${ }^{1}$ \\ ${ }^{1}$ Sekolah Menengah Atas Negeri 1 Tanah Abang, Indonesia
}

\begin{tabular}{l} 
Article Info \\
\hline Article history: \\
Received Jun $12^{\text {th }}, 2021$ \\
Revised Aug $20^{\text {th }}, 2021$ \\
Accepted Aug $26^{\text {th }}, 2021$ \\
\hline
\end{tabular}

\section{Keyword:}

Motivation

Work environment

Discipline level

\begin{abstract}
The study aims to determine the impact of work environment and motivation on teachers's discipline level at SMAN 1 Abab. This study uses a quantitative study technique, that involves 56 teachers at SMAN 1 Abab. Data collection techniques used questionnaire that filled out by teachers. Studies have shown that work environment and motivations affect teacher discipline levels.
\end{abstract}

(C) 2021 The Authors. Published by IICET.

This is an open access article under the CC BY-NC-SA license (https://creativecommons.org/licenses/by-nc-sa/4.0

\section{Corresponding Author:}

Setyani, S.,

Sekolah Menengah Atas Negeri 1 Tanah Abang, Indonesia

Email: setyani107@gmail.com

\section{Introduction}

Human resources are one of the resources that exist in a company / organization / educational institution in addition to other resources, such as capital, materials, machinery and technology. Nowadays, it is increasingly recognized by many that in running the wheels of a company / organization / educational institution, humans are the most important element. This is because it is humans who manage other resources in the company / organization, so that it becomes useful and without human resources other resources are meaningless. Given that human resources are the most important element, the maintenance of continuous and harmonious relationships in an educational institution is very important.

Work environment factors also play a very important role in shaping individual behavior and achievement in educational institutions. The work environment can be defined as everything that is around the teachers and which can influence the teachers in carrying out the tasks assigned to them. The work environment in question is a physical and non-physical work environment. These two components of environmental factors, if they can be created properly, will support the organization's efforts in achieving organizational goals.

The current work environment at SMA Negeri $1 \mathrm{Abab}$ is deemed inadequate. In terms of the availability of working facilities, it is still very limited. So that the implementation of services to students in the context of teaching and learning and the completion of administrative activities is hampered. Because the working teachers must take turns using school facilities. In addition, the condition of work comfort is still not felt by teachers. 
Discipline factors play an important role in the implementation of educational workforce. A teacher who has a high level of discipline will continue to work well even without being supervised by the principal. An undisciplined teacher will steal work time to do other things that are not useful in the learning process. Likewise, teachers who have the discipline to obey the rules like professional teachers without any coercion from any party. In the end, teachers who have high discipline will have good performance because their time will be used properly to carry out the work that has been determined.

[1] Motivation is a behavioral activity that works in an effort to meet desired needs. For each individual actually has a motivation that is able to become a spirit in spurring and fostering work enthusiasm at work. The spirit possessed by a person can come from himself or from outside, where the two forms will be better if both of them are together to drive one's motivation.

Motivation is a tendency for a person to involve himself in activities that lead to goals. If the behavior leads to an object or target, with this motivation the maximum achievement of the target or target will be obtained so that the implementation of the task can be done as well as possible, so that work effectiveness can be achieved.

Based on the author's direct observation as one of the teachers in Penukal Abab Lematang Ilir Regency, there are several obstacles in implementing discipline, including the low awareness of education personnel to take action and being disciplined in carrying out tasks such as low motivation, late entry to work, and lack of a supervisory system. A lack of supervisory equipment will be able to open up opportunities for educational personnel to carry out various budgeting.

Thus, based on the descriptions above, the researcher is interested in making the research title "The Impact of Work Environment and Motivation on Teachers's Discipline Level at SMAN 1 Abab".

\section{Method}

\section{Types of Research}

The method used in this research is a questionnaire, namely the primary data collection technique by asking several questions in writing with alternative answers submitted to the respondent. The research instrument used to collect the research data was to distribute questionnaires to educators. Meanwhile, the questionnaire items are made in the form of multiple choices, where each question member consists of five alternative answers.

Then the respondent's answer data were scored using the Likert scale system, with alternative answer choices 1 to 5 with the following conditions:

1. $\sqrt{ }$ Score 5 for the answers strongly agree.

2. $\sqrt{ }$ Score 4 for the agreed answers.

3. $\sqrt{ }$ Score 3 for doubtful answers.

4. $\sqrt{ }$ Score 2 for the answers disagree.

5. $\sqrt{ }$ Score 1 for the answers strongly disagree.

\section{Research Subjects and Data}

The object of research can be defined as the subject matter to be investigated in order to obtain more targeted data. The research objects in this paper include: (1) Work environment (2) Motivation (3) Teachers's Discipline Level at SMA Negeri 1 Abab. In 2020, there are 56 educational staff at SMA Negeri 1 Abab, Penukal Abab Lematang Ilir (PALI) Regency. However, the large number of existing employees cannot guarantee that SMA Negeri $1 \mathrm{Abab}$ will be better and more advanced, if this is not supported by the discipline of the SMA Negeri 1 Abab Education Staff. This can be seen from the many industrial actions carried out by SMA Negeri 1 Abab teachers.

\section{Results and Discussions}

The quantitative analysis used in this study aims to determine the effect of discipline and work environment on teacher performance at SMAN 1 Abab. Regression analysis is used to predict how far the dependent value will change if the value of the independent variable is manipulated / fluctuating or increases and decreases.

The multiple linear regression formula used in this study is as follows: 


$$
\mathrm{Y}=\mathrm{a}+\mathrm{bX} 1+\mathrm{BX} 2
$$

Note:

$\mathrm{Y}=$ dependent variable

$\mathrm{a}=$ Intercept (constant price)

$\mathrm{b}=$ Regression Coefficient

$\mathrm{X}=$ Independent Variable [2]

To determine the relationship between motivation, work environment, and the level of discipline of teachers at SMAN $1 \mathrm{Abab}$, the authors use the correlation coefficient formula:

\begin{tabular}{lc}
\hline Interval Coefficient & Relationship Level \\
$0,000-0,199$ & Very Low \\
$0,200-0,399$ & Low \\
$0,400-0,599$ & Moderate \\
$0,600-0,799$ & High \\
$0,800-1,000$ & Very High \\
\hline
\end{tabular}

Source: [3]

The level of significance in this study used $a=0.05$ or $5 \%$. What is meant by null hypothesis (Ho) and alternative hypothesis $(\mathrm{Ha})$ are:

1. Ho $=\mathrm{r} 1<0=$ It means that there is no relationship between discipline on teacher performance.

2. $\mathrm{Ha}=\mathrm{r} 1>0=$ It means that there is an relaationship between discipline on teacher performance.

3. $\mathrm{Ho}=\mathrm{r} 2<0=$ It means that there is no relationship between the work environment on teacher performance.

4. Ho $=\mathrm{r} 2>0=$ It means that there is an relationship between the work environment and teacher performance.

To determine whether the variable weight together has an effect on the dependent variable, the $\mathrm{F}$ test is used with the following criteria:

1. If $\mathrm{F}$ count $>\mathrm{F}$ table, then $\mathrm{Ho}$ is rejected and $\mathrm{Ha}$ is accepted.

2. If $\mathrm{F}$ count $<\mathrm{F}$ table, then $\mathrm{Ho}$ is accepted and $\mathrm{Ha}$ is rejected.

\section{Conclusions}

The following findings are derived based on the study result: 1) There is a relationship between motivation and teachers's discipline level. 2) There is a relationship between work environment and teachers's discipline. 3) Both motivation and work environment are affect to teachers's discipline level. 4) Studies have shown that work environment and motivations affect teacher discipline level at SMA.

\section{References}

[1] Fahmi, Irham, 2017. Analisis Laporan Keuangan. Alfabetta. Bandung.

[2] Sugiyono. 2008. Cetakan kelima, Statistika Untuk Penelitian. Alfabetta, Bandung.

[3] Supriyatno, 2008. Metodologi Riset Bisnis. PT. Indeks. Jakarta. 